\title{
目
}

Arch. Min. Sci. 62 (2017), 3, 621-637

Electronic version (in color) of this paper is available: http://mining.archives.pl

DOI 10.1515/amsc-2017-0045

ROBERT RANOSZ*\#

DETERMINANTS OF INTEREST RATES ON CORPORATE BONDS OF MINING ENTERPRISES

\author{
DETERMINANTY OPROCENTOWANIA OBLIGACJI KORPORACYJNYCH \\ Z UWZGLĘDNIENIEM SEKTORA GÓRNICZEGO
}

\begin{abstract}
This article is devoted to the determinants of interest rates on corporate bonds of mining enterprises. The study includes a comparison between the cost of foreign capital as resulting from the issue of debt instruments in different sectors of the economy in relation to the mining industry. The article also depicts the correlation between the rating scores published by the three largest rating agencies: S\&P, Moody`s, and Fitch. The test was based on simple statistical methods. The analysis performed indicated that there is a dependency between the factors listed and the amount of interest rates on corporate bonds of global mining enterprises. Most significant factors include the rating level and the period for which the given series of bonds was issued. Additionally, it is not without significance whether the given bond has additional options. Pursuant to the obtained results, is should be recognized that in order to reduce the interest rate on bonds, mining enterprises should pay particular attention to the rating and attempt to include additional options in issued bonds. Such additional options may comprise, for example, an ability to exchange bonds to shares or raw materials.
\end{abstract}

Keywords: mining corporate bonds, convertible bonds, callable and puttable bonds, bond's coupon

Niniejszy artykuł został poświęcony determinantom oprocentowania obligacji korporacyjnych spółek górniczych. Do głównych czynników mających znaczący wpływ na wartość kuponu obligacji zaliczono: okres do wykupu obligacji, poziom ratingu oraz rodzaj obligacji. Każda z wymienionych zmiennych może wpływać na obniżenie oraz na podwyższenie wartości kuponu (oprocentowania) obligacji. Celem niniejszego opracowania jest zbadanie zależności pomiędzy kuponem a wymienionymi determinantami. Opracowanie zawiera również porównanie kosztu kapitału obcego wynikającego z emisji instrumentów dłużnych różnych sektorów gospodarki w stosunku do sektora górniczego. W artykule zbadano również korelację pomiędzy udzielanymi ratingami publikowanymi przez trzy największe agencje ratingowe, do których zaliczono: S\&P, Moody`s oraz Fitch. Do przeprowadzenia badania wykorzystano proste metody statystyczne. Przeprowadzona analiza wykazała, iż istnieje zależność pomiędzy wymienionymi czynnikami a wartością oprocentowania obligacji emitowanych przez przedsiębiorstwa górnicze na świecie.

* AGH UNIVERSITY OF SCIENCE AND TECHNOLOGY, FACULTY OF MINING AND GEOENGINEERING, AL. MICKIEWICZA 30, 30-059 KRAKOW, POLAND

\# Corresponding author: rranosz@agh.edu.pl 


\begin{abstract}
Należy również stwierdzić, iż do najważniejszych należy zaliczyć poziom ratingu oraz okres na jaki została wyemitowana dana seria obligacji. Nie bez znaczenia jest również to czy dana obligacja posiada opcje dodatkowe. Na podstawie otrzymanych wyników należy stwierdzić, iż przedsiębiorstwa górnicze w celu obniżenia oprocentowania obligacji powinny zwracać szczególną uwagę na rating oraz starać się zwierać opcje dodatkowe w emitowanych przez siebie obligacjach. Taką opcją dodatkową może być na przykład możliwości zamiany obligacji na akcje czy też surowiec.
\end{abstract}

Słowa kluczowe: górnicze obligacje korporacyjne, obligacje zamienne, obligacje callable i puttable, kupon obligacji

\title{
1. Introduction
}

Credit risk is one of the main parameters determining the financial decisions of investors (Onorato \& Altman, 2005). Undoubtedly, such risk affects economic and financial decisions made by mining companies, which determine their value (Kustra \& Kubacki, 2009). Credit risk is especially significant in the case of mining investment projects. It is mainly associated with the specificity of the performed investments, which are characterised by long periods and relatively long positive cash flows. Therefore, appropriate and objective risk determination is extremely important for defining the value of the bond's coupon, i.e. the interest on bonds, but also their profitability (bond yield) (Tang, 2009). The article focuses on bonds which, in comparison with traditional sources of financing (bank credits), are a more flexible form of debt (Sierpińska \& Bąk, 2013). These are the challenges faced by the rating agencies when defining the credit risk of an investment, e.g. the bonds issued by individual economic entities (Chorafas, 2005). This article focuses on the three largest rating agencies, namely S\&P, Moody`s, and Fitch (Fischer, 2015). Since objectivity is important when estimating the level of risk, it is thus possible to assume that the levels of risk as described by the above-mentioned agencies should be similar (Haspolat, 2015). F.K. Reilly and K.C. Brown state that the rating scores given by the largest rating agencies are usually similar, and, in case of any disproportions, the issue is called the "divisible rating" issue (Reilly \& Brown, 2001). The objective of this article is to determine the factors influencing the value of the bond's coupon with respect to bonds issued by mining companies. The rating as the parameter defining the level of risk surely affects the value of the bond's coupon. This correlation is also mentioned by F.K. Reilly and K.C. Brown (Reilly \& Brown, 2001). E.F. Brigham and J.F. Houston state that bonds with lower rating scores have a higher value of the bond's coupon rates than bonds with higher rating scores (Brigham \& Houston, 2005). Apart from the rating score, the amount of the interest rates on bonds is also influenced by the loan size (Asquith et al., 2013). Nowadays, bonds with additional options, such as the possibility of debt-to-share conversion or earlier redemption, are becoming more and more popular. Such factors may also influence the interest on bonds. According to F.K. Reilly and K.C. Brown, treasury bonds and corporate bonds are not so closely correlated with the macroeconomic conditions or the nature of the risk of the issue or issuer. Investors investing in bonds distinguish four elements contributing to the investment risk, and state that the following factors have an impact on the value of the coupon (Reilly \& Brown, 2001): bond rating level, maturity, additional contractual terms, and conditions of the issue, such as, e.g. the possibility of earlier redemption, and impact of the rating in the country of origin of a given issuer (Reilly \& Brown, 2001). This publication concentrates on the first three factors affecting the value of the bond's coupon. 


\section{Rating agencies}

Credit rating agencies assess the relative credit risk. Currently, a number of such companies operate in the market. For example, according to the list of registered and certified rating agencies (2012/C 33/08), 29 rating agencies (RPEiR, 2009) currently function in the market. The most important ones are S\&P, Moody`s, and Fitch. The total share of these three agencies in the global market is $90 \%$, which is illustrated in figure 1 . Therefore, the article is devoted to these three rating agencies. One of the main goals of risk assessment by way of rating is to strive at harmonising market information, which is usually divergent and asymmetrical. However, it is not an easy task, which proves the fact that the values of rating scores given by the particular rating agencies are not identical (Langhor \& Langhor, 2008). The rating agencies and their impact on the economies of countries and companies have been the subjects of many studies and publications. Particular attention was given thereto after 2008, when their reliability was examined (Mathis et al., 2009). One of the bases of such activities were doubts and objections regarding the very procedure of giving rating scores where the costs are covered by the issuer and not the investor interested in valuation. The situation forces us to give serious thought to the level of independence of the rating agencies (Bonsall IV, 2014). The authors John (Xuefeng) Jiang, Mary Harris Stanford, and Yuan Xie show that the adopted rule, according to which the issuer pays for the rating score, causes an increase of the rating score of a company (Jiang et al., 2012). The rating score of a company may also be given in the event when a given company did not request the same. As it turns out, the markets react to such information (usually in a negative manner) provided that the rating score was not based on public financial data (Behr \& Güttler, 2008). Winnie P.H. Poon shows that the rating scores of companies which did not request the same are lower than in the case of the companies which requested such a rating, even when considering the rating score of a country and key financial features (Poon, 2003). The article: "Rating as a Useful Tool for Credit Risk Measurement" presents the procedure of giving a rating score based on the financial statements of companies (Weissova et al.,2015). It was also shown that companies were trying to run their businesses in such a manner as to influence the received rating score (Alissa et al., 2013). The authors John R Graham and Campbell R Harvey decided that apart from the assessment of the financial liquidity of an economic entity, in the policy of shaping the structure of the company's capital (debt management), the risk assessment level in the form of a rating score was also important (Graham and Harvey, 2001; Graham et al., 2005). It was also stated that the capital structure of the companies adapted more quickly in more developed countries (Huang and Shen, 2015). In addition, it was shown that the rating score was an important factor influencing the manner of managing an enterprise (corporate governance) (Bereskin et al., 2015; Ashbaugh-Skaife et al., 2006). The rating score given by the agencies may impact not only the enterprise which receives it, but also the industry in which it operates (suppliers and recipients of a given company in both the vertical and horizontal structure) (Chang et al., 2015). The authors Tyler R. Henry, Darren J. Kisgen and Juan (Julie) Wu noticed that the reduction of share prices translated into lower rating scores of particular companies, whereas increased rating scores had no significant impact on the change of share prices of the assessed company (Henry et al., 2015). The studies concerning the correlation between the rate of return for shares and credit risk level allowed to observe certain anomalies. Usually, if the risk is high, the investors expect a higher rate of return in exchange for assuming the risk, whereas in the case of lower risk, it is possible to expect that the rates of return shall be lower. The studies conducted by Emawtee Bissoondoyal- 
Bheenick and Doron Avramov show that the above-mentioned rule is not confirmed in the case of Australian, Japanese and American markets (Bissoondoyal-Bheenick, 2015; Avramov et al., 2009). Furthermore, it was shown that the forecast rating has a very strong impact on the bond and share market (Pukthuanthong-Le et al.,2007; Hooper et al., 2008), as well as on the companies outside a given country (Gande \& Parsley, 2005; Ferreira \& Gama, 2007; Ismailescu \& Kazemi, 2010). Within the framework of research into the signs (forecast) of rating levels of particular companies, it was also stated that they may help to predict a difficult situation in the company even one year before (Sy, 2004).

When analysing a rating and its impact on the financial market, the impact of legal restrictions and regulations on improving the accuracy and reliability of the assessment performed by the particular rating agencies (Cheng \& Neamtiu, 2009), as well as on the consequences of introducing the "list of observed issuers" as a means of the monitoring and regulation of market details regarding the financial situation of companies were also taken into consideration (Bannier \& Hirsch, 2010).

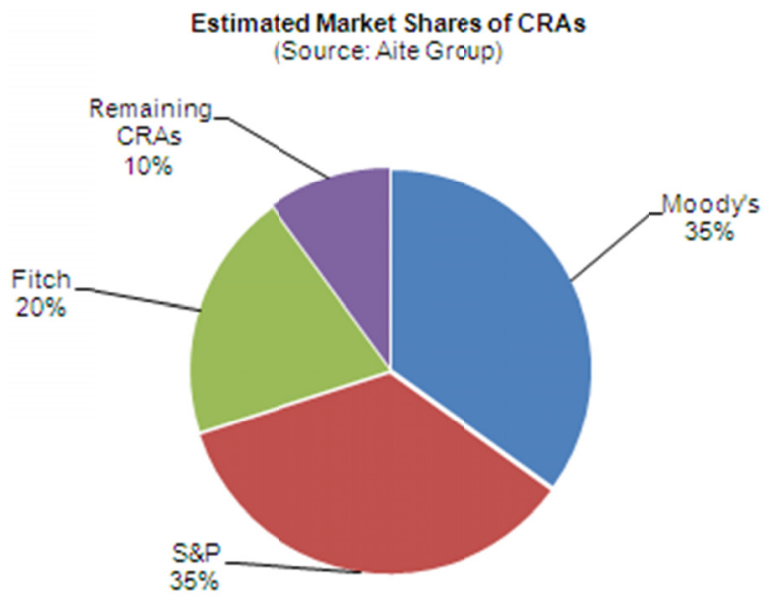

Fig. 1. Market share of the rating agencies

According to this chapter, the rating agencies and their scores have a significant impact on the functioning of companies in a number of aspects of their operations. In the subsequent part of the article, the impact of the rating score on the cost of capital obtained through corporate bonds (the bond's coupon) for mining enterprises shall be explored.

\section{Methodology}

Assuming that risk is an objective phenomenon for each entity, it should be stated that regardless of the methodology of the study and company performing such a study, the level of risk estimated by the individual rating agencies should be similar. This fact is also pointed out by F.K. Reilly and K.C. Brown, who have stated that the total scores of the main rating agencies should be similar (Reilly \& Brown, 2001). The studies reported herein provide the credit risk 
assessments of the three largest rating agencies. To evaluate the level of objectivity and independence of ratings and, hence, the level of value similarities in the case of rating scores given by the rating agencies - on the basis of a database including nearly 20000 (Finra, 2015) bonds issued within the last 18 years by economic entities from different sectors, almost 10,000 issues rated by at least 2 rating agencies for the same company and the same issue were selected. The database was created with the aid of computer software that searches bonds issue databases such as finra-markets.morningstar.com and others. The included data concerns both small and large mining enterprises from around the world. For the purpose of analysis, it was assumed that the maximum time difference between the rating scores given by different agencies may not be longer than 30 days. Another condition is the fact that the rating score must be given to exactly the same company and issue. To conduct the analysis it is required to standardise the rating scores in the individual agencies by assigning values from 1 to 24 for the least risky to the most risky, respectively. The standardisation process is shown in table 1.

TABLE 1

Standardised rating scale for the three main agencies

\begin{tabular}{|c|c|c|c|c|c|}
\hline \hline Moody's & Points & S\&P & Points & Fitch & Points \\
\hline Aaa & 1 & AAA & 1 & AAA & 1 \\
\hline Aa1 & 2 & AA+ & 2 & AA+ & 2 \\
\hline Aa2 & 3 & AA & 3 & AA & 3 \\
\hline Aa3 & 4 & AA- & 4 & AA- & 4 \\
\hline A1 & 5 & A+ & 5 & A+ & 5 \\
\hline A2 & 6 & A & 6 & A & 6 \\
\hline A3 & 7 & A- & 7 & A- & 7 \\
\hline Baa1 & 8 & BBB+ & 8 & BBB+ & 8 \\
\hline Baa2 & 9 & BBB & 9 & BBB & 9 \\
\hline Baa3 & 10 & BBB- & 10 & BBB- & 10 \\
\hline Ba1 & 11 & BB + & 11 & BB+ & 11 \\
\hline Ba2 & 12 & BB & 12 & BB & 12 \\
\hline Ba3 & 13 & BB- & 13 & BB- & 13 \\
\hline B1 & 14 & B+ & 14 & B+ & 14 \\
\hline B2 & 15 & B & 15 & B & 15 \\
\hline B3 & 16 & B- & 16 & B- & 16 \\
\hline Caa1 & 17 & CCC+ & 17 & CCC & 17 \\
\hline Caa2 & 18 & CCC & 18 & CCC & 18 \\
\hline Caa3 & 19 & CCC- & 19 & CCC & 19 \\
\hline Ca & 20 & CC & 20 & CCC & 20 \\
\hline Ca & 21 & C & 21 & CCC & 21 \\
\hline C & 22 & D & 22 & DDD & 22 \\
\hline C & 23 & D & 23 & DD & 23 \\
\hline C & 24 & D & 24 & D & 24 \\
\hline
\end{tabular}

Thanks to the standardisation process, it was possible to identify a correlation between the individual rating agencies as regards similarities in the rating scores given. The results are presented in table 2 (correlations between the individual rating scores) and figure 2. 
Values of correlation factors between the results of the largest rating companies

\begin{tabular}{|c|c|c|c|}
\hline & Moody`s & S\&P & Fitch \\
\hline Moody`s & $100.0 \%$ & $93.4 \%$ & $85.2 \%$ \\
\hline S\&P & $93.4 \%$ & $100.0 \%$ & $92.9 \%$ \\
\hline Fitch & $85.2 \%$ & $92.9 \%$ & $100.0 \%$ \\
\hline
\end{tabular}

According to the results provided in table 2 and figure 2, the credit risk assessments by the largest rating companies are similar. S\&P and Moody`s show a high correlation between their results, whereas Fitch seems to be more independent as a rating agency (Alsakka \& Gwilym, 2012). A similar correlation was shown in rating scores given to countries (Bozic \& Magazzino, 2013). Nonetheless, it should be mentioned at this point that such correlation may not occur between the aforesaid (the largest) rating agencies, but between the agencies operating within the territories of particular countries. For example, it may be due to the asymmetry of the data used and information access (Ismail et al., 2015). The authors Yoon S. Shin and William T. Moore point out that the rating scores given by the three largest agencies are usually lower than the scores given to Japanese companies by Japanese rating agencies (Shin \& Moore, 2003). Richard Cantor and Frank Packer stress that the differences may result from the different models used to provide credit rating assessments (Cantor \& Packer, 1997). Miles Livingston, Andy Naranjo and Lei Zhou note that in the case of split ratings of bonds issued by a given company there is a greater probability that the rating score shall be changed in the future (usually up to a year) (Livingston et al., 2008). Some authors also point out that the differences in the rating scores may be caused by a lack of transparency in the issuer's assets of a given series of bonds (Morgan, 2002; Livingston et al., 2007). On the basis of the performed analysis, it might be stated that further analyses aimed at finding, for example, the correlations between the rating score and the interests on the bonds may be conducted based on the assessment by only one of the aforementioned rating agencies, as the results should be representative and reliable for the entire market.

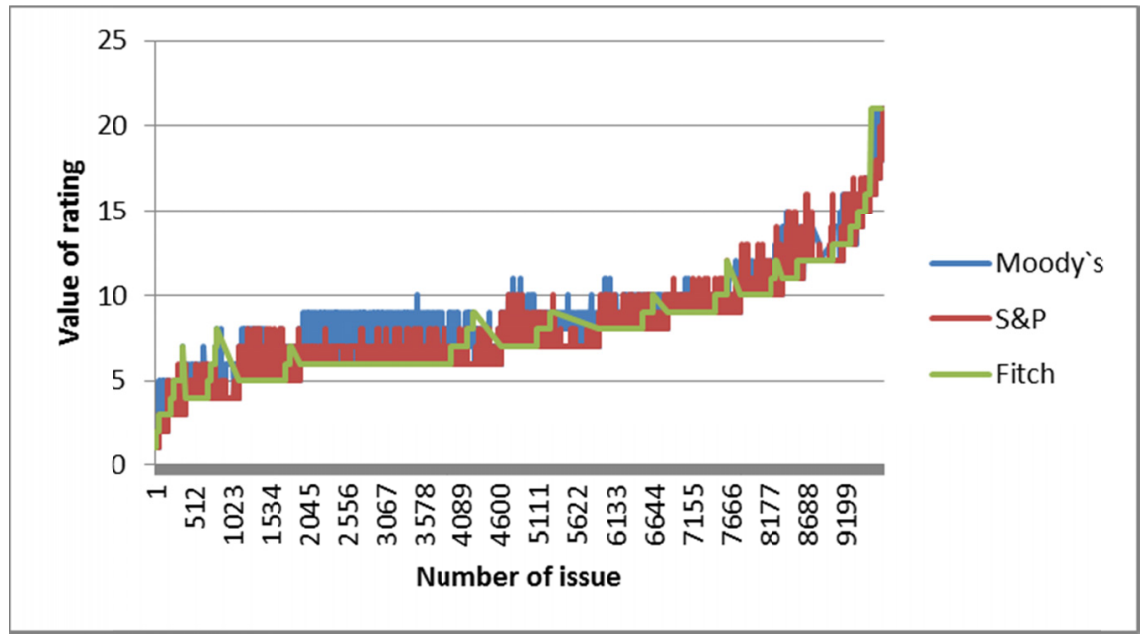

Fig. 2. Rating variability for the individual issues 
On the basis of data collected from the mining industry, which cover the period of the last 18 years, the factors influencing the coupon rates with respect to bonds issued by different mining companies were examined. Within the framework of the study, the following factors were distinguished: rating, maturity and types of bonds. The types of bonds are the following:

- All bonds - all bonds regardless of whether they have additional options or not.

- Ordinary bonds - bonds without any additional options; ordinary corporate bond's coupons.

- Callable bonds - bonds with a call option.

- Puttable bonds - bonds with a put option.

- All convertible bonds - bonds convertible to shares, regardless of whether they have additional options or not (except for the option allowing conversion to shares).

- Ordinary convertible bonds - convertible bonds which have no other option apart from the option already mentioned herein.

- Convertible callable bonds - bonds convertible to shares, with the additional call option.

- Convertible puttable - bonds convertible to shares, with the additional put option.

The following chapter presents correlations between the rating score and value of the coupon in the context of the maturity, correlation between the rating score and the coupon in the context of the selected types of bonds, and correlation between the value of the coupon and convertible bonds. The article also examines the correlation between the bond's coupon and bond rating for particular sectors.

\section{Bond's coupon and affecting variables}

\subsection{Rating and maturity}

The first examined factor is the correlation between the bond's coupon rates in mining companies and the bond rating within particular maturity periods, including specific groups of bonds. The maturity refers to the period for which the bonds were issued. To simplify and make the obtained results more legible, it was decided to present the maturity in different time frames. Four time frames have been determined: the first issue period up to 5 years, the second - from 5 to 10 years, the third - from 10 to 20 years, and the last period - over 20 years. The obtained results were presented in four groups: the first group including all bonds regardless of the embedded options (all bonds), the second group, where the bonds with the "put" and "call" options have been omitted (ordinary bonds), the third group including the bonds with the call option (callable bonds), and the fourth group including the bonds with the put option (puttable bonds). The results of the performed analysis are presented in figure 3 (the designations in accordance with table 1 are used in figure 3).

When analysing the results presented in figure 3 , it is possible to explicitly state that in the case of mining corporate bonds the bond's coupon rate definitely depends on the rating value, but also on the maturity. Figure 3a presents the correlation between the rating and the value of the coupon (for all bonds). On the basis of the presented results it must be stated that the longer the maturity, the less sensitive such a bond becomes to the rating. On the basis of figure $3 \mathrm{a}$, it is also evident that the higher the rating (minimum credit risk), the lower the interest on the bond. The results for ordinary bonds are outlined in figure $3 \mathrm{~b}$. Similarly to the group of all bonds, in 
a) All bonds

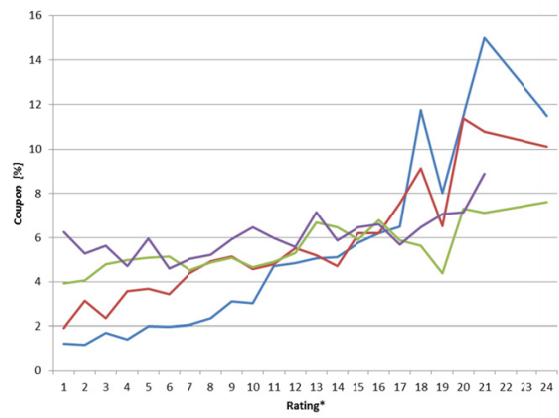

c) Callable bonds

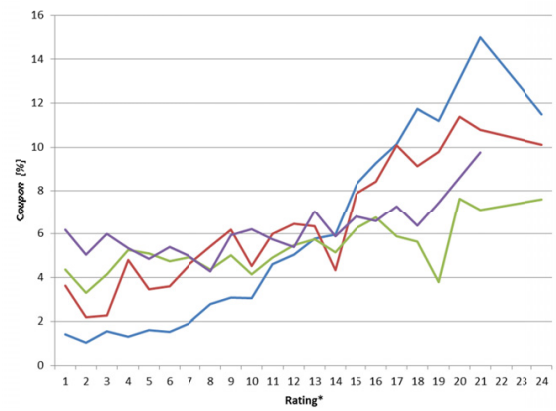

b) "Ordinary" bonds
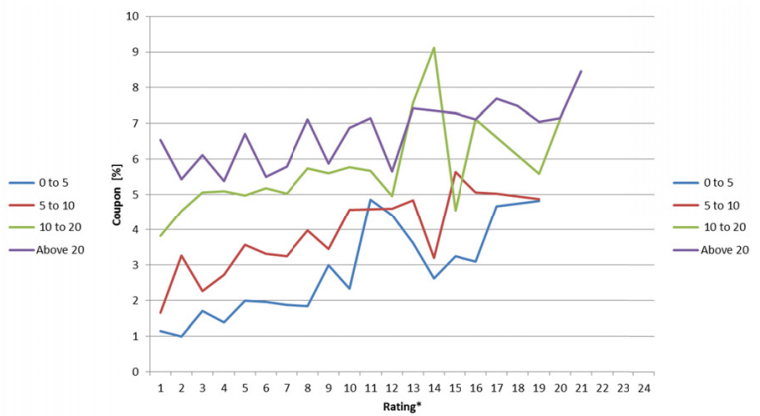

d) Puttable bonds

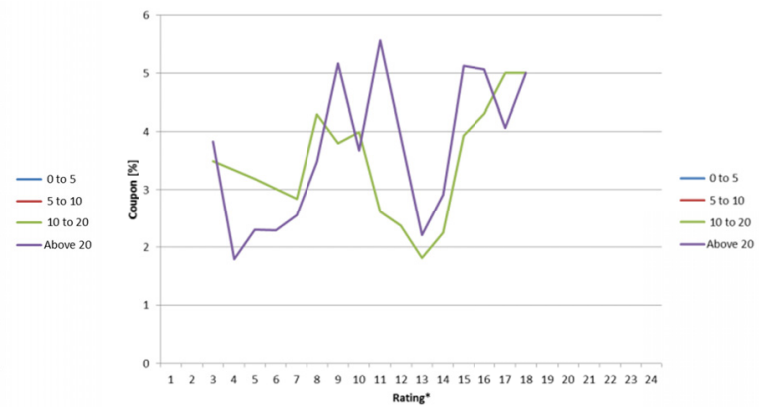

Fig. 3. The correlation between the bond's coupon and the bond rating for the particular bond periods, including specific groups of bonds

the case of "ordinary" bonds, the correlation between the value of the coupon and the rating score also exists (the higher the risk, the more expensive the bonds). When examining callable bonds, the results presented in figure $3 \mathrm{c}$ have been obtained. The results correspond to the correlations for the group of all bonds. The last type of bonds examined in this group are puttable bonds (Fig. 3d). Puttable bonds are not so popular as callable bonds. Based on the issue of the instruments with such an option, it is evident that the issues are made by companies for a period of at least 10 years. The aforesaid figure does not present any significant correlations between the risk and the amount of the coupon. This may be due to the fact that puttable bonds provide the bondholder with the possibility of requesting earlier maturity from the issuer, which translates into the reduction of the issuer's insolvency risk.

\subsection{Rating and selected types of bonds}

This subchapter examines the correlation between the rating score and the bond's coupon depending on the analysed group of bonds: all, ordinary, callable and puttable bonds. The obtained results have been presented in four groups depending on the maturity: the first group includes bonds with a maturity of up to 5 years, the second group - from 5 to 10 years, the third group - 
from 10 to 20 years, and the last group (fourth) - maturity longer than 20 years. The results of these considerations are presented in figure 4.

When analysing figure 4, it may be stated that there is a correlation between the type of bond and the interest charged thereon. The correlation discussed in the previous subchapter, according to which higher risk means higher value of the coupon, is also confirmed. According to figure 4 , puttable bonds are issued by mining companies for a period of at least 10 years. As can be seen from figures $4 \mathrm{c}$ and $4 \mathrm{~d}$, puttable bonds are the cheapest source of capital for the issuer, and bear the lowest risk from among the bonds considered in the above-mentioned analysis. The differences between callable and ordinary bonds may be observed only in figures $4 \mathrm{a}$ and $4 \mathrm{~b}$. The aforementioned figures explicitly show that callable bonds are the most expensive. Their high cost is linked with their characteristics. From the point of view of the bondholder, bonds with the possibility of earlier maturity bear risk (related to earlier redemption of the bonds by the issuer) that may be compensated by a lower issue price or higher interest on bonds (Fabiozzi, 2000; Brigham \& Houston, 2005). In the case of callable and ordinary bonds the difference becomes less prominent as regards the issue of the bonds, whose maturity is longer than 10 years.

a) Period of the issue from 0 to 5 years

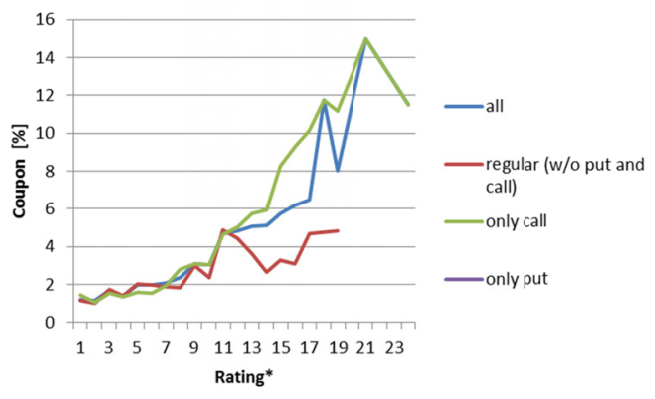

c) Period of the issue from 10 to 20 years

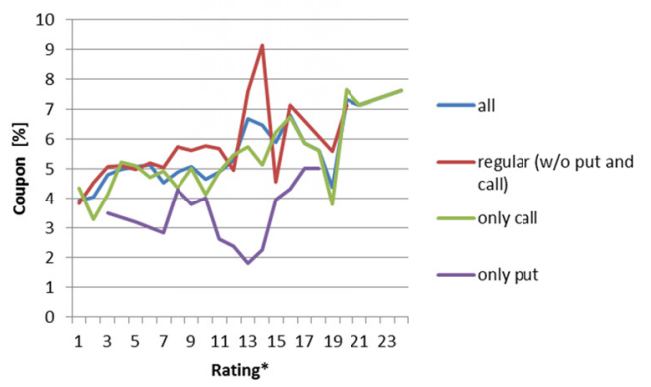

b) Period of the issue from 5 to 10 years

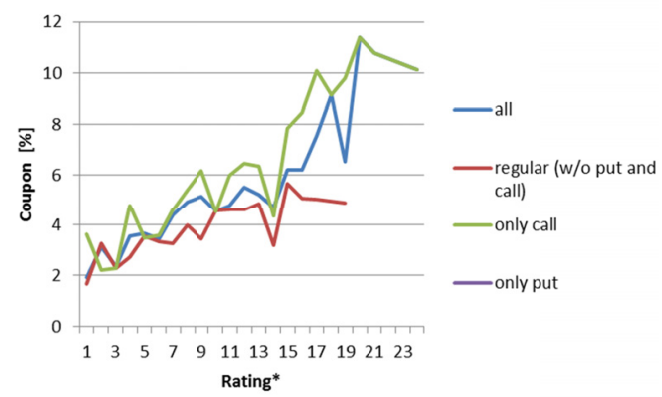

d) Period of the issue over 20 years

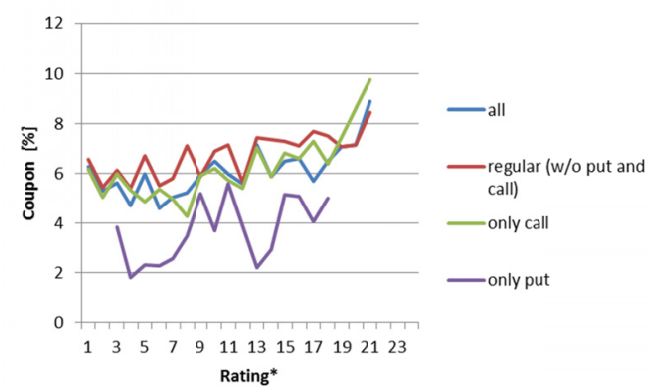

Fig. 4. Correlation between the coupon and the bond rating for particular groups of bonds, including the individual periods of the issue 


\subsection{Rating and convertible bonds}

The factor that has not been considered so far concerns bonds convertible to shares, so-called convertible bonds. H.B. Mayo states that convertible bonds are attractive for investors since they have safety features characteristic of debt instruments (Mayo, 1997). It should also be noted that bonds convertible to shares may constitute another option in the issued bond, and therefore it was decided to analyse these types of bonds in the context of: all bonds and ordinary bonds (without put and call options) and in the context of bonds with such options already embedded therein, namely callable and puttable bonds. F.J. Fabiozzi states that the additional option affects the value of the difference between the return rate as offered by a given issue and the return rate on comparable bonds. The author also argues that if the issue of the bonds has embedded additional options that award bonuses to the issuer, the market participants expect that the difference between the return rate on such an issue and the return rate on the comparable bonds shall be higher than in the case of ordinary bonds. On the other hand, if the additional option awards bonuses to the investor, the market shall be satisfied with lower margins than in the case of ordinary bonds (Fabiozzi, 2000). The results of the analysis regarding all bonds and ordinary bonds are shown in figure 5 . It was decided to present the obtained results in four groups of time frames: the first group with bonds with a maturity of up to 5 years, the second group with bonds issued for a period from 5

a) Period of issue from 0 to 5 years

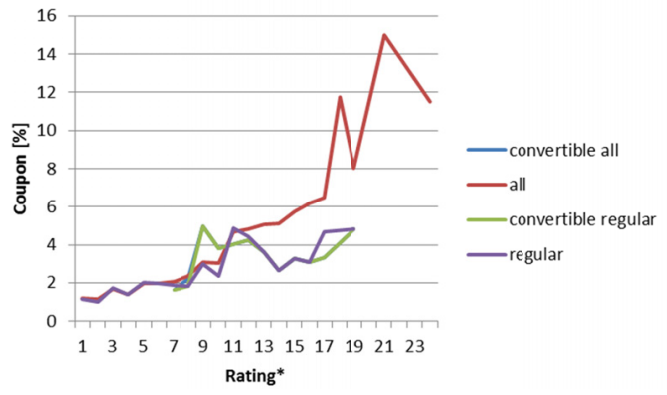

c) Period of issue from 10 to 20 years

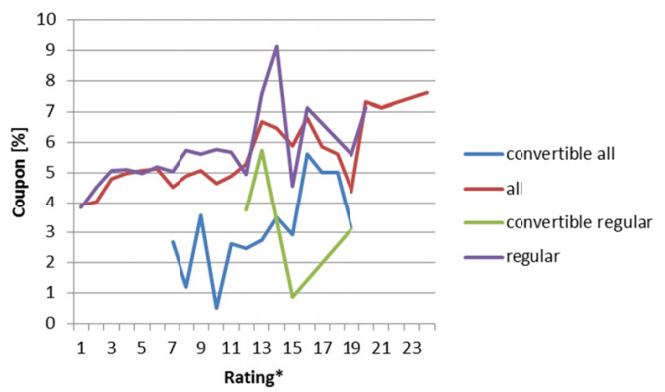

b) Period of issue from 5 to 10 year:

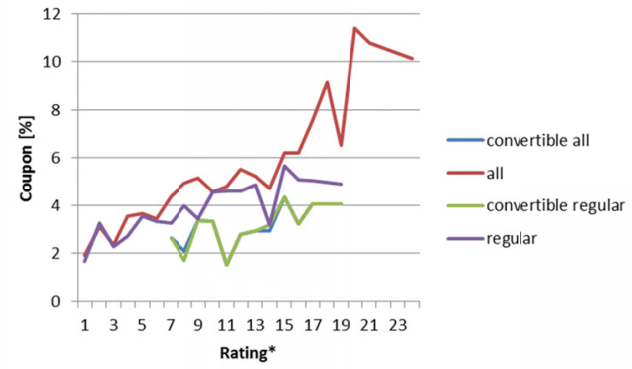

d) Period of issue over 20 years

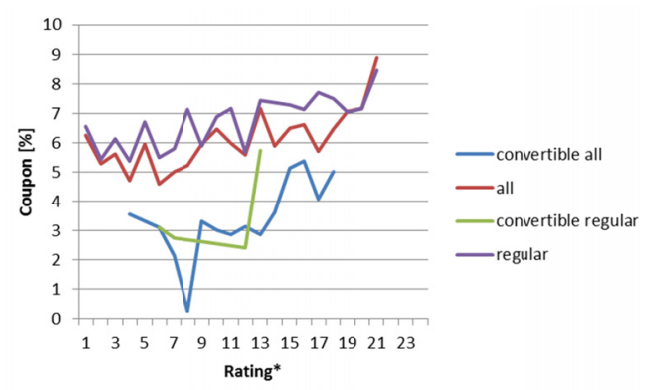

Fig. 5. Correlation between the coupon and the bond rating for particular types of bonds, including the individual periods of issue 
to 10 years, the third group with bonds issued for a period from 10 to 20 years, and the last group with bonds issued for periods longer than 20 years.

According to the presented results, the additional option embedded in the bonds allowing the conversion of debt into capital of the company issuing the bonds affects the amount of interest on bonds. It may be stated that if the bond may be converted into shares, the value of the coupon shall be lower. On the basis of figure 5, the interest rate is lower if the maturity is longer. Subsequently, bonds in the case of which the possibility of conversion into shares constitutes another option, have been analysed. Due to the fact that the number of issued bonds with a maturity shorter than 10 years during the examined period was insignificant, issues with a maturity of over 10 years have been analysed. The results of the analysis are presented in figure 6 .

a) Period of issue from 10 to 20 years

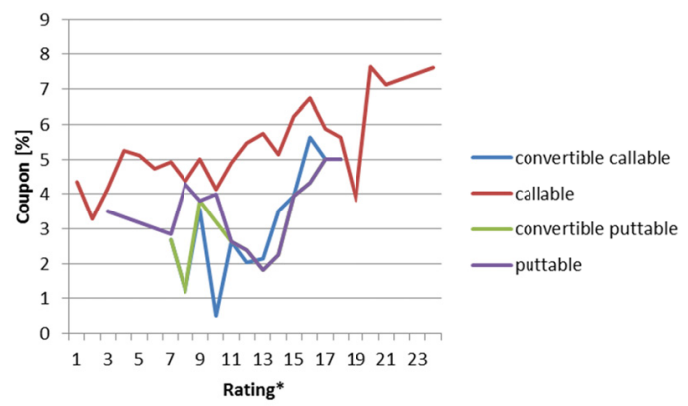

b) Period of issue over 20 years

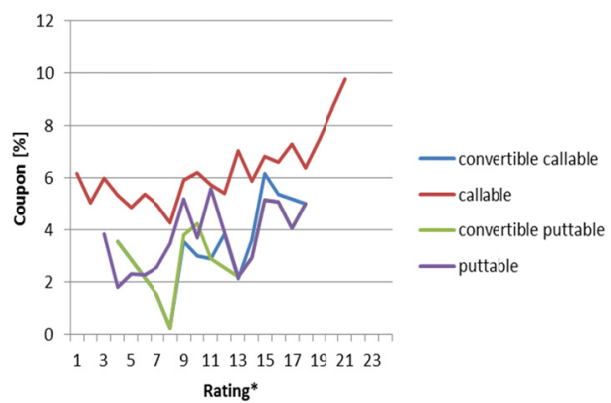

Fig. 6. Correlation between the coupon and the bond rating for particular types of bonds, including the individual periods of issue

The results of the analysis presented in figure 6 show that the additional (second) option embedded in the bonds does not always contribute to a decrease in the value of the coupon. Even though in the case of callable bonds the additional option in the form of a possibility of converting debt into shares brings positive results and decreases the value of the coupon, in the case of puttable bonds, this additional option seems to be absolutely irrelevant.

On the basis of the present considerations, many factors affect the value of the bond's coupon. The analysis has not included the sectors from which the particular companies came from as every such company has already been assessed by the rating agency, and the credit risk assessment has been expressed by the score given. Since the origin of the company may be important in terms of shaping the correlations between the rating score and the value of the coupon, it was decided to consider the impact of such factor. The obtained results are presented in figure 7.

On the basis of figure 7, the values of the coupons for particular bonds are similar and behave in accordance with the general rule that higher rating means higher interest on bonds. Additionally, according to figure 7 , it is possible to conclude that bonds issued by global companies from the mining industry are more attractive than issues of companies from other sectors included in the analysis. Figure 7 also suggests that in the event when the rating value exceeds 10 (Table 1), the origin of the company is irrelevant. 

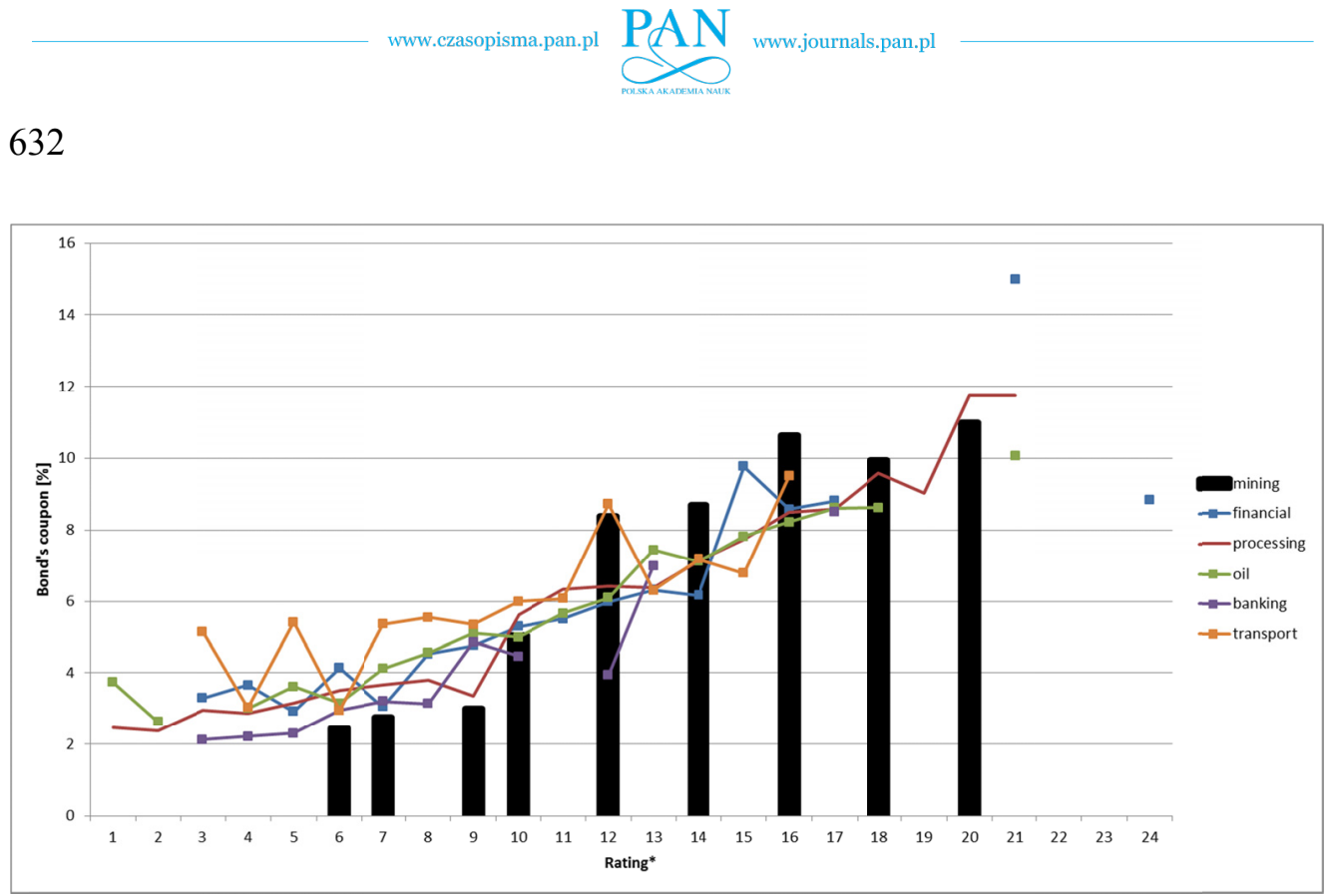

Fig. 7. Correlation between the coupon and bond rating for particular sectors

\subsection{Multiple regression analysis in the context of interest rates on bonds}

This part of the article contains an assessment of the weights of particular factors that may influence the interest rates on bonds issued by mining companies. The following parameters have been included in the analysis of the impact of the factors on the value of the coupon: type of bonds, rating, period that the bond is issued for. Detailed data concerning the types of bonds are included in table 3.

Types of sectors and types of bonds considered in the multiple regression analysis

\begin{tabular}{|c|c|}
\hline \hline Type of bond & Designation in the analysis \\
\hline Debentures & BT1 \\
\hline Convertible & BT2 \\
\hline Securitised & BT3 \\
\hline Insured & BT4 \\
\hline
\end{tabular}

The bond rating used in the multiple regression analysis (forward stepwise regression) has been based on the data included in table 1. The input data for the analysis included the issue of debt securities (bonds) by mining companies in the years 2005-2014. The study results are presented in table 4 and figure 8 . The obtained results correspond to the value of the adjusted $R^{2}=0.68 \%$. The obtained value corresponds to 5 factors presented in table 4 . Therefore, there are some premises which allow us to acknowledge that the aforementioned factors describe the value of the coupon at $68 \%$. Other factors (apart from those presented in table 4 ) in table 3 increase the value of the adjusted $R^{2}$. However, such increases have no significant impact. 
Results for the multiple regression analysis using the forward stepwise method

\begin{tabular}{|c|c|c|c|c|c|c|c|}
\hline \hline Factor & Step & $\begin{array}{c}\text { Multiple - } \\
\text { Spearman }\end{array}$ & $\begin{array}{c}\text { Multiple - } \\
\text { R-square }\end{array}$ & $\begin{array}{c}- \text { R-square } \\
- \text { change }\end{array}$ & $\begin{array}{c}\text { F-to- } \\
\text { introduce/delete }\end{array}$ & $\mathbf{p}$ & $\begin{array}{c}\text { Variables - } \\
\text { included }\end{array}$ \\
\hline Rating & 1 & 0.513713 & 0.263901 & 0.264 & 899.15 & 0 & 1 \\
\hline YEARS & 2 & 0.733211 & 0.537599 & 0.274 & 1483.906 & 0 & 2 \\
\hline BT2 & 3 & 0.801426 & 0.642283 & 0.105 & 733.369 & 0 & 3 \\
\hline Call & 4 & 0.817234 & 0.667871 & 0.026 & 192.99 & 0 & 4 \\
\hline BT3 & 5 & 0.824718 & 0.68016 & 0.012 & 96.208 & 0 & 5 \\
\hline
\end{tabular}

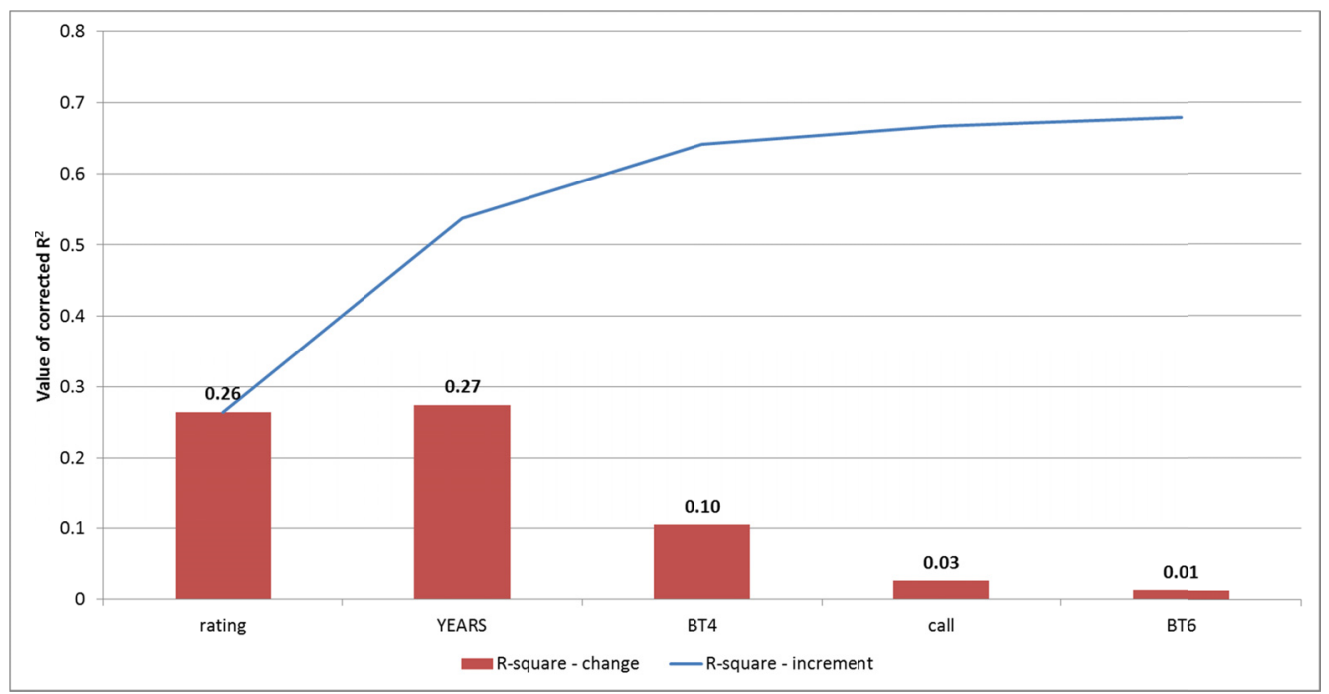

Fig. 8. Cumulative (blue) and normal (red) value of the adjusted $R^{2}$ for the particular factors included in the analysis

The results in table 4 and figure 8 constitute grounds for concluding that the following three factors have the most important impact on the value of the bond's coupon with respect to the bonds of mining companies: rating, maturity (YEARS) and the possibility of converting bonds into shares (BT2). Other factors influence the value of the bond coupon to a lesser extent, yet they are still significant. Nonetheless, the results of the stepwise regression do not explain whether a given factor contributes to the decrease or increase of the value of the coupon. The answer to this question is the result of the multiple regression analysis in the form of the function presented in the formula (1) and the graphic display in figure 9.

$$
\begin{aligned}
\text { Bond's coupon }=3.1 & +0.29 * \text { rating }+0.093 * \mathrm{LAT}-4.64 * \mathrm{BT} 2+ \\
& +0.31 * \text { call }-0.3 * \mathrm{BT} 3
\end{aligned}
$$

where:

The designations are in accordance with table 1. 


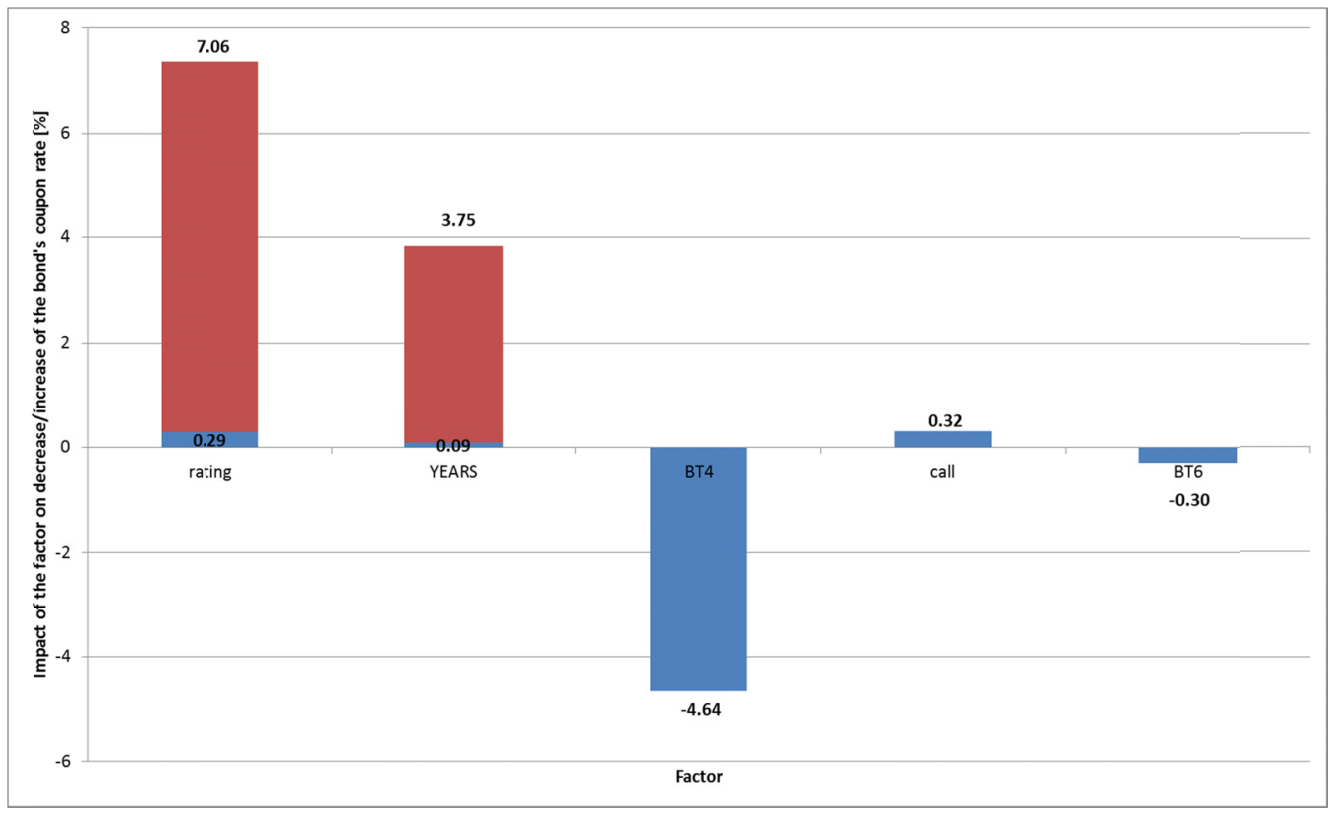

Fig. 9. Factors influencing the value of the bond's coupon, including their weights *blue - impact of a single factor; *red - rating score of 24 (in accordance with table 1); *red - YEARS (the period that the bond is issued for -40 years)

According to the formula (1) and figure 9, the factors considered in the analysis, which affect the value of the interest on bonds issued by the mining companies, may be divided into two groups. The first group includes those that increase the value of the coupon, and the second includes those that decrease the value. The first group of factors includes such variables as: the rating score (rating), the period that the bond is issued for (YEARS), callable bonds (call). The second group includes such variable as: convertible bonds (BT2) and securitisation bonds (BT3).

\section{Conclusion}

On the basis of the collected data and the performed analysis, the correlation between the bond's coupon rate (the interest on bonds in the mining sector) and particular variables, such as the maturity, rating or type of the issued bonds may be confirmed. It should also be stated that the origin of bonds (the sector from which a given company originates) may not be significant in terms of shaping the bond's coupon value (such a statement is a reason for further studies in that respect). No significant correlation between the value of the coupon and interest on bonds may be due to the fact that the risk of a given sector and company has been included in the rating score of individual economic entities. Nonetheless, based on the performed analysis it is evident (Fig. 7) that global mining companies have minimally lower interest on bonds in the case of the same risk level compared with other sectors. The factors with the greatest impact on the value 
of the mining bond's coupon are the following: rating of a given issue, maturity, and the fact of whether a bond has an option allowing the bondholder to convert it into shares of the issuer of a debt security. The most important factors determining the increase of the bond's coupon are the following:

- bond rating - if the bonds have the highest rating, " 1 ", the coupon is increased by 0.29 percentage points; when the rating is the lowest rating, " 24 ", the coupon is increased by 6.96 percentage points,

- the period that the bond is issued for (YEARS) - if the issue is for 1 year, the value of the bond's coupon shall be increased by only 0.093 percentage points, whereas if the bond is issued for a period of, e.g. 40 years - the coupon shall be increased by 3.72 percentage points.

The main factor decreasing the value of the coupon is the issue of bonds with an option allowing its conversion into shares. In such a case, the obtained result indicates that the amount of the interest rate may be decreased by up to 4.64 percentage points. At this point, it should be mentioned that other factors included in the multiple regression analysis may impact the decrease or increase of the value of the coupon. However, such an impact is not as significant as in the case of the above-mentioned factors.

\section{References}

Aitegroup 2015. http://www.aitegroup.com/report/nationally-recognized-tatistical-ratings-organizations-nothing-lastsforever.

Alissa W., Bonsall IV S.B., Koharki K., Penn Jr. K.M.W., 2013. Firms' use of accounting discretion to influence their credit ratings. Journal of Accounting and Economics 55, 2-3, April-May 2013, 129-147.

Alsakka R., Gwilym O., 2012. Rating agencies'credit signals: An analysis of sovereign watch and outlook. International Review of Financial Analysis 21, January 2012, 45-55.

Ashbaugh-Skaife H., Collins D.W., LaFond R., 2006. The effects of corporate governance on firms' credit ratings. Journal of Accounting and Economics 42, 1-2, October 2006, 203-243.

Asquith P., Au A.S., Covert T., Pathak P.A., 2013. The market for borrowing corporate bonds. Journal of Financial Economics 107, 1, January 2013, 155-182.

Avramov D., Chordia T., Jostova G., Philipov A., 2009. Credit ratings and the cross-section of stock returns. Journal of Financial Markets 12, 3, August 2009, 469-499.

Bannier Ch.E., Hirsch Ch.W., 2010. The economic function of credit rating agencies - What does the watchlist tell us?. Journal of Banking \& Finance 34, 12, December 2010, 3037-3049.

Behr P., Güttler A., 2008. The informational content of unsolicited ratings. Journal of Banking \& Finance 32, 4, April 2008, 587-599.

Bereskin F.L., Kim B., Dongchuhl Oh.F., 2015. Do credit rating concerns lead to better corporate governance? Evidence from Korea. Pacific-Basin Finance Journal 35, Part B, November 2015, 592-608.

Bissoondoyal-Bheenick E., Brooks R., 2015. The credit risk-return puzzle: Impact of credit rating announcements in Australia and Japan. Pacific-Basin Finance Journal 35, Part A, November 2015, 37-55.

Bonsall IV S.B., 2014. The impact of issuer-pay on corporate bond rating properties: Evidence from Moody's and S\&P'S initial adoptions. Journal of Accounting and Economics 57, 2-3, April-May 2014, 89-109.

Bozic V., Magazzino C., 2013. Credit Rating Agencies: The Importance of Fundamentals in the Assessment of Sovereign Ratings. Economic Analysis and Policy 43, 2, September 2013, 157-176.

Brigham E.F., Houston J.F., 2005. Podstawy zarządzania finansami. 1. PWE Warsaw. 
Cantor R., Packer F., 1997. Differences of opinion and selection bias in the credit rating industry. Journal of Banking \& Finance 21, 10, October 1997, p. 1395-1417.

Chang J.H., Hung M.W., Tsai F.T., 2015. Credit contagion and competitive effects of bond rating downgrades along the supply chain. Finance Research Letters, In Press, Corrected Proof, Available online 24 October 2015. http://ac.els-cdn.com/S1544612315001014/1-s2.0-S1544612315001014-main.pdf?_tid=8f365068-9992-11e5-b63a-00000aab0f26\&acdnat $=1449129225$ ca8c3103c60b48f9a4a200a4880aef40

Cheng M., Neamtiu M., 2009. An empirical analysis of changes in credit rating properties: timeliness, accuracy and volatility. Journal of Accounting and Economics 47, 108-130.

Chorafas D.N., 2005. Bank loans and securitization. The Management of Bond Investments and Trading of Debt, 2005, $119-141$.

Fabiozzi F.J., 2000. Rynki obligacji analiza i strategie. Wydawnictwo Finansowe WIG-PRESS, Warsaw.

Ferreira M.A., Gama P.M., 2007. Does sovereign debt ratings news spill over to international stock markets?. Journal of Banking \& Finance 31, 10, October 2007, 3162-3182.

Finra, 2015. http://finra-markets.morningstar.com.

Fischer T., 2015. Market structure and rating strategies in credit rating markets - A dynamic model with matching of heterogeneous bond issuers and rating agencies. Journal of Banking \& Finance 58, September 2015, 39-56.

Fitch 2015. https://www.fitchratings.com.

Graham J.R., Harvey C.R., 2001. The theory and practice of corporate finance: evidence from the field. Journal of Financial Economics 60, 2-3, May 2001, 187-243.

Graham J.R., Harvey C.R., Rajgopal S., 2005. The economic implications of corporate financial reporting. Journal of Accounting and Economics 40, 1-3, December 2005, 3-73.

Gande A., Parsley D.C., 2005. News spillovers in the sovereign debt market. Journal of Financial Economics 75, 3 , March 2005, 691-734.

Haspolat F.B., 2015. Analysis of Moody's Sovereign Credit Ratings: Criticisms Towards Rating Agencies Are Still Valid?. Procedia Economics and Finance 30, 283-293.

Henry T.R., Kisgen D.J., Wu J., 2015. Equity short selling and bond rating downgrades. Journal of Financial Intermediation 24, 1, January 2015, 89-111.

Hooper V., Hume T., Kim SJ., 2008. Sovereign rating changes - Do they provide new information for stock markets? Economic Systems 32, 2, June 2008, 142-166.

Huang Y.L., Shen Ch.H., 2015. Cross-country variations in capital structure adjustment - The role of credit ratings. International Review of Economics \& Finance 39, September 2015, 277-294.

Ismail A., Oh S., Arsyad N., 2015. Split ratings and debt-signaling in bond markets: A note. Review of Financial Economics 24, January 2015, 36-41.

Ismailescu I., Kazemi H., 2010. The reaction of emerging market credit default swap spreads to sovereign credit rating changes. Journal of Banking \& Finance 34, 12, December 2010, 2861-2873.

Jiang J., Stanford M.H., Xie Y., 2012. Does it matter who pays for bond ratings? Historical evidence. Journal of Financial Economics 105, 3, September 2012, 607-621.

Kustra A., Kubacki K., 2009. Dylematy kierunków wzrostu wartości przedsiębiorstw górniczych: fuzje i przejęcia czy eksploracja?. Gospodarka Surowcami Mineralnymi, (25/2).

Langhor H.M., Langhor P.T., 2008. The rating agencies and their credit ratings. New York: John Wiley \& Sons, 111.

Livingston M., Naranjo A., Zhou L., 2007. Asset opaqueness and split bond ratings. Financial Management, Autumn $36,49-62$.

Livingston M., Naranjo A., Zhou L., 2008. Split bond ratings and rating migration. Journal of Banking \& Finance 32 , 8, August 2008, 1613-1624.

Mathis J., McAndrews J., Rochet JC., 2009. Rating the raters: Are reputation concerns powerful enough to discipline rating agencies?. Journal of Monetary Economics 56, 5, July 2009, 657-674.

Mayo H.B., 1997. Wstep do inwestowania. LIBER, Warsaw.

Moodys 2015. https://www.moodys.com.

Morgan D.P., 2002. Rating banks: Risk and uncertainty in an opaque industry. American Economic Review 92, 874-888. 
Onorato M., Altman E.I., 2005. An integrated pricing model for defaultable loans and bonds. European Journal of Operational Research 163, 1, 16 May 2005, 65-82.

Poon W.P.H., 2003. Are unsolicited credit ratings biased downward?. Journal of Banking \& Finance 27, 4, April 2003, 593-614.

Pukthuanthong-Le K., Elayan F.A., Rose L.C., 2007. Equity and debt market responses to sovereign credit ratings announcement. Global Finance Journal 18, 1, 2007, 47-83.

Reilly F.K., Brown K.C., 2001. Analiza inwestycji i zarzadzania portfelem. 2. PWE Warsaw.

RPEiR. 2009. Regulation (EC) No 1060/2009 of the European Parliament and of the Council of 16 September 2009 on credit rating agencies (regulation on credit rating agencies).

Shin Y.S., Moore W.T., 2003. Explaining credit rating differences between Japanese and U.S. agencies. Review of Financial Economics 12, 4, 2003, 327-344.

S\&P, 2015. www.standardandpoors.com.

Sierpińska M., Bąk P., 2013. Rola obligacji korporacyjnych w finansowaniu przedsiębiorstw sektora górniczego w Polsce. Gospodarka Surowcami Mineralnymi 29, book 1.

Sy A.N.R., 2004. Rating the rating agencies: Anticipating currency crises or debt crises?. Journal of Banking \& Finance 28, 11, November 2004, 2845-2867.

Tang T.T., 2009. Information asymmetry and firms'credit market access: Evidence from Moody's credit rating format refinement. Journal of Financial Economics 93, 2, August 2009, 325-351.

Weissova I., Kollar B., Siekelova A., 2015. Rating as a Useful Tool for Credit Risk Measurement. Procedia Economics and Finance 26, 278-285. 